\title{
Correlation of Arch Length and Width to Anteroposterior Lip Position in Class I Non Extraction Malocclusion
}

\author{
Ulfi Fatwa Khasni \\ Department of Orthodontic \\ Faculty of Dentistry, Universitas Sumatera Utara \\ Medan, Indonesia \\ ulfikhasni@gmail.com
}

\author{
Muslim Yusuf \\ Department of Orthodontic \\ Faculty of Dentistry, Universitas Sumatera Utara \\ Medan, Indonesia
}

\author{
Nurhayati Harahap \\ Department of Orthodontic \\ Faculty of Dentistry, Universitas Sumatera Utara \\ Medan, Indonesia
}

\begin{abstract}
The purpose of this study was to determine the correlation between the anteroposterior position of the lips against changes in the length and width of the dental arch in Class I malocclusion non extraction. The sample was 30 patients PPDGS Orthodontic clinic of FKG USU. The sample used was 30 before treatment study models, 30 after treatment study models, 30 before treatment lateral cephalometric photograph, and 30 after treatment lateral cephalometric photograph. The study was conducted by measuring the width of interpremolar, intermolar and arch length of study models and the position of the upper lip and lower lip to e-line of lateral cephalometric photograph. The data was processed with SPSS and data normality was tested by Mann Whitney test. There is no correlation statistically between the before and after treatment of anteroposterior lip position against changes in the length and width of the dental arch before and after treatment. There is no correlation between the anteroposterior lip position against changes in the length and width of the dental arch in Class I malocclusion non extraction.
\end{abstract}

\section{Keywords-anteroposterior lip, arch length, arch width}

\section{INTRODUCTION}

Orthodontic is a branch of dentistry that plays role in prevention and treatment of malocclusions and other abnormalities in the dentofacial region [1,2]. Appropriate goals for correcting malocclusions resulting in proper functional and structural occlusion and aesthetic faces and optimal teeth [1,2,3] To obtain satisfaction with orthodontic treatment, clinicians need the ability to develop optimal treatment plan and mastery the techniques for different types of malocclusions [2,3].

Occlusion is a pattern in which the maxillary and mandible teeth interact each other in the position and movement of mandible [1,4]. According to Canut, the normal occlusion objectives are concrete to be achieved by orthodontists to achieve structural, functional and esthetic forms [1]. According to Angle, Class I malocclusion is characterized by a normal molar teeth anteroposterior relationship, where there is no skeletal change site, either in the transverse or vertical plane, and no dental changes $[3,4]$.

The dental arch is a curve formed by the crown of the teeth, which is a combined reflection of tooth crown, the position and inclination of teeth, lips, cheeks, and tongue [5]. Measurements were made on the dimensions of wide and arch arches [6]. The analysis of width and length of dental arch can be performed on the study model. There are two commonly analyzes used generally, namely Pont analysis and Korkhaus analysis. Both of these indices use the same of interpremolar and intermolar reference point in determination of the index. The most widely used analysis is the Pont. The Pont analysis is used to diagnose the narrow, wide, or normal width of the dental arch required as a basis for the planned treatment of whether dental arch lateral expansion, in the premolar or molar region. While the curved analysis according to Korkhaus is done by measuring the distance from the most anterior point of the labial surface of the maxillary first incisor to the perpendicular to the line connecting the interpremolar pin point of Pont reference [5,7].

The controversy over the effects of tooth extraction on aesthetic smiles leads to debates on treatment with extraction and non-extraction [8,9]. Many things to consider in determining a treatment requires extraction or not. According to Baurind, there are three major considerations in the selection of treatments with extraction or non-extraction of teeth, including the degree of severity of crowding teeth, the protrusive degree of incisor teeth, and in cases requiring improved facial profiles. The development of science and technology in the field of orthodontics allows many non-extraction treatment options, such as interproximal 
dental grinding of teeth, protracted, and expansion of dental arch and molar distalization [9].

One stage in determining the diagnosis and plan of orthodontic treatment in appropriate Class I malocclusion is through model analysis, which includes analysis of the arch length and width. In addition, the selection of non-extraction treatments will affect changes in the arch length, width and the anteroposterior position of lips. The aim of the study was to examine the correlation of arch length and width to anteroposterior lip position in class I non extraction malocclusion.

\section{MATERIALS AND METHODS}

The research is descriptive observational research with cross-sectional research design. The sample used 30 study models of before and after treatment, non extraction class I malocclusion that came to RSGMP FKG USU. Category of skeletal malocclusion is Class I (ANB $2 \pm 2$ ) and MP-SN is normal $(32 \pm 5)$ for men and women. The sample age range is $17-35$ years old with all permanent tooth, except for molar 3. No interproximal grinding, interproximal fillings on measured tooth, and tooth extraction.

The research procedure is done by several stages of collecting model studies, taking cephalometry photographs based on specified inclusion and exclusion criteria. Measurement of the dental arch length and width before and after treatment was done on the dental mold sample model. The dental arch width is performed by measuring the interpremolar distance and the intermolar width obtained by direct measurement (on the model). The dental arch length according to Korkhaus is done by measuring the distance from the mesial contact of the maxillary central incisor to the line connecting the interpremolar Pont wide reference point. In one day, the measurement of dental study model was only done as much as 4-5 pairs of dental models to avoid the eyestrain of the researchers while reading the scale contained in the calipers, so that the data obtained more accurate. To obtain valid data, operator test is done first, that is operator measuring 4 pairs of study model before and after orthodontic treatment in 2 times. If the first calculation result with the second calculation is not having different meaning, then the operator is eligible to perform the measurement. To see the results of measurements, statistical tests were performed.

Tracing of lateral cephalometric photographs before and after treatment by first determining the E-line based on Ricketts with the reference point is the Pronasal point (Prn): taken from the highest nose tip; Pogonion point $(\mathrm{Pg})$ : the lowest point on the chin then drawn a line from Pronasal to Pogonion. To determine the anteroposterior position of the upper lip, then measured the distance from between the upper lip to E-line Ricketts (Ls-E) and to determine the anteroposterior position of the lower lip then measured the distance between the lower lips to the E-line. The measured results are recorded, then processed and analyzed.

\section{RESULTS}

The data will be analyzed analytically to test the normality of the data by using Mann Whitney test. The results of this test indicate that the data is not normally distributed ( $\mathrm{p}<0.05)$. Table $\mathrm{I}$ is a different test table of maxillary and mandibular interpremolar (IP) calculations before and after treatment with fixed orthodontic planes in Class I malocclusion patients. The numerical data from this table shows that the highest interpremolar (IP) value is in the maxillary model after treatment was $38.357 \pm 2.843$, while the lowest interpremolar (IP) value was in the mandible model before treatment $(34.852 \pm 4.513)$. From Table I also can be seen that the maxillary interpremolar width before treatment did not have statistically significant differences with maxillary interpremolar width after treatment $(p>0.05)$, while mandibular interpremolar width before treatment had statistically significant difference with interpremolar width of the mandible after treatment $(\mathrm{p}<0.05)$.

TABLE I. INTERPREMOLAR WIDTH (IP) MAXILLARY AND MANDIBULAR WIDTH TEST VALUES BEFORE AND AFTER TREATMENT IN CLASS I MALOCCLUSIONS.

\begin{tabular}{|c|c|c|c|}
\hline Variable & Mean & SD & p \\
\hline IP maxillary before treatment & 37.730 & 4.140 & \multirow{2}{*}{0.290} \\
\hline IP maxillary after treatment & 38.357 & 2.843 & \\
\hline $\begin{array}{l}\text { IP mandibular before } \\
\text { treatment }\end{array}$ & 34.852 & 4.513 & \multirow[t]{2}{*}{$0.049 *$} \\
\hline IP mandibular after treatment & 36.588 & 4.828 & \\
\hline
\end{tabular}

Table II is a different test table of maxillary and mandibular intermolar (IM) calculations before and after treatment with fixed orthodontic planes in Class I malocclusion patients. The numerical data from this table shows that the highest intermolar (IM) value is in the mandibular model after treatment that is $46,792 \pm$ 4,716 , while the lowest intermolar (IM) width value was in the mandibular model before treatment that is $44.308 \pm 3.343$. From Table II it can also be seen that the maxillary intermolar width before treatment did not have statistically significant difference with maxillary intermolar width after treatment $(p>0.05)$, whereas the mandibular intermolar width before treatment has statistically significant differences with the mandibular intermolar width after treatment $(\mathrm{p}<0.05)$.

TABLE II. INTERMOLAR WIDTH (IM) MAXILLARY AND MANDIBULAR WIDTH TEST VALUES BEFORE AND AFTER TREATMENT IN CLASS MALOCCLUSIONS.

\begin{tabular}{|c|c|c|c|}
\hline Variable & Mean & SD & p \\
\hline IM maxillary before treatment & 45.988 & 3.708 & \multirow{2}{*}{0.663} \\
\hline IM maxillary after treatment & 45.663 & 3.420 & \\
\hline IM mandibular before treatment & 44.308 & 3.343 & \multirow{2}{*}{$0.013 *$} \\
\hline IM mandibular after treatment & 46.792 & 4.716 & \\
\hline
\end{tabular}

Table III is a different test table showing the anteroposterior position of the upper lip and lower lip to E-line Ricketts before and after treatment in Class I 
malocclusion patient. The numerical data from this table shows that the highest anteroposterior position value is on the lower lip to E- Line after treatment is $2.050 \pm 2.394$. While the lowest anteroposterior position is on the upper lip of the E-line before treatment is $-0.685 \pm 2.884$. From Table IV it can also be seen that upper lip positions on E-line before treatment did not have statistically significant differences with upper lip position on E-line after treatment ( $p>0.05)$, while the lower lip position on Eline before treatment had statistically significant differences with lower lip position on E-line after treatment $(\mathrm{p}<0.05)$.

TABLE III. TEST VALUES OF ANTEROPOSTERIOR POSITIONS OF UPPER LIP AND LOWER LIP BEFORE AND AFTER TREATMENT IN CLASS I MALOCCLUSION

\begin{tabular}{|c|c|c|c|}
\hline Variable & Mean & SD & p \\
\hline $\begin{array}{l}\text { Upper lip position to E-line before } \\
\text { treatment }\end{array}$ & -0.685 & 2.884 & \multirow{2}{*}{0.489} \\
\hline $\begin{array}{l}\text { Upper lip position to E-line after } \\
\text { treatment }\end{array}$ & -0.150 & 2.649 & \\
\hline $\begin{array}{l}\text { Lower lip position to E-line before } \\
\text { treatment }\end{array}$ & 0.717 & 2.299 & \multirow{2}{*}{$0.030^{*}$} \\
\hline $\begin{array}{l}\text { Lower lip position to E-line after } \\
\text { treatment }\end{array}$ & 2.050 & 2.394 & \\
\hline
\end{tabular}

Table IV is a table showing the correlation between the upper and lower lip anteroposterior positions against the maxillary and mandible intermolar (IM) width before and after treatment in Class I malocclusion. The numerical data indicates a correlation between the upper lip anteroposterior positions prior to treatment of the maxillary intermolar width before treatment $(r=0.73)$, but the correlation did not have a significant difference $(\mathrm{p}>0.05)$.

TABLE IV. CORRELATION VALUES OF ANTEROPOSTERIOR POSITIONS OF UPPER LIP AND LOWER LIP TO MAXILLARY AND MANDIBULAR INTERMOLAR (IM) WIDTHS BEFORE AND AFTER TREATMENT IN CLASS I MALOCCLUSIONS

\begin{tabular}{|l|c|c|}
\hline \multicolumn{1}{|c|}{ Variable } & $\mathbf{~}$ & $\mathbf{p}$ \\
\hline $\begin{array}{l}\text { Anteroposterior position of upper lip before } \\
\text { treatment to IM maxillary before treatment }\end{array}$ & 0.73 & 0.70 \\
\hline $\begin{array}{l}\text { Anteroposterior position of upper lip after } \\
\text { treatment to IM maxillary after treatment }\end{array}$ & 0.22 & 0.24 \\
\hline $\begin{array}{l}\text { Anteroposterior position of lower lip before } \\
\text { treatment to IM mandibular before treatment }\end{array}$ & -0.09 & 0.65 \\
\hline $\begin{array}{l}\text { Anteroposterior position of lower lip before } \\
\text { treatment to IM mandibular after treatment }\end{array}$ & 0.09 & 0.65 \\
\hline
\end{tabular}

\section{DISCUSSION}

The result show that the interpremolar and intermolar maxillary and mandibular values were changed before and after treatment with fixed orthodontic plane used in Class I malocclusion patients which can be seen in Table I and Table II. From the research results, it can be seen that the significant difference is seen only in interpremolar mandibular width before and after treatment, but not significant in the maxillary arch. The results of this study (Table III) showed that lower lip position to E-line before treatment had significant differences with lower lip position on E-line after treatment $(p<0.05)$. Table IV, showed a correlation of only one variable, the anteroposterior position of the upper lip prior to treatment of the maxillary intermolar width before treatment, but this variable also has no significant difference $(p>0.05)$. The other three variables do not show any correlation.

There are changes in the size of the dental arch width before and after treatment with fixed plane in a non-extraction Class I malocclusion patient. However, significant differences are found only in changes of the interpremolar width of the mandible, intermolar mandibular and lower lip anteroposterior position against the mandible before and after treatment. There was no statistically significant difference in interpremolar maxillary width, intermolar maxillary width; maxillary curve length, mandibular arch length and anteroposterior lip position before and after treatment but clinically values were altered.

The correlation was present only in the anteroposterior position of the upper lip prior to treatment of intermolar maxillary width before treatment, but did not have a significant difference $(\mathrm{p}>$ $0.05)$. There is no correlation in other variables. Statistically, there was no correlation between changes in the length and width of the dental arch to anteroposterior lip positions in patients with nonextraction Class I malocclusion in this study.

\section{REFERENCES}

[1] C.B. Arcis, J.M. Montiel, J.M.A. Silla. (2015, September 28) Orthodontic treatment need: An epidemiological approach. Available: http://cdn.intechopen.com/pdfs-wm/31371.pdf. (September 28.2015)

[2] S.E. Bishara, et al., "Comparison of the dental arch change in patients with class II, division 1 malocclusion: extraction vs nonextraction treatment," The Angle Orthodontist, vol. 64(5), pp. $351-358,1994$

[3] I.T.P. Silva, "Angle class I malocclusion treated with extraction of first permanent molars," Dental Press J. Orthod., vol. 15(4), pp. 133-143, 2010.

[4] R. Hassan, A.K. Rahimah, "Occlusion, malocclusion, and method of measurements - an overview," Archives of Orofacial Sciences, vol. 2, pp. 3-9, 2007.

[5] G.A.M.D.H. Paramesthi, C.A. Farmasyanti, D. Karunia, "Besar indeks Pont dan Korkhaus serta hubungan antara lebar dan panjang lengkung gigi terhadap tinggi palatum pada suku Jawa," Maj. Ked. Gigi, vol. 18(1), pp. 6-10, 2011

[6] R.E. Moyers, Handbook of orthodontics, $4^{\text {th }}$ eds., London: Year Book Medical Publisher Inc., 1998, pp. 121-124,186,233.

[7] G.A.M.D.H. Paramesthi, C.A. Farmasyanti, D. Karunia, "10 hubungan antara lebar dan panjang lengkung gigi terhadap tinggi palatum pada Suku Jawa dengan metode Pont dan Korkhaus," Maj. Ked. Gigi, vol. 18(1), pp. 6-10, 2011.

[8] E. Kim, A.A. Gianelly, "Extraction vs. non extraction: Arch widths and smile esthetics," Angle Orthodontist, vol. 73(4), pp. 354-358, 2003.

[9] Erliera, H.S. Anggani, "Hal-hal yang harus dipertimbangkan dalam menentukan indikasi ekstraksi atau non-ekstraksi pada perawatan ortodonti," Dentika Dent. J., vol. 11(2), pp.198-202, 2006.

[10] G. Singh, ed., Textbook of orthodontics, $2^{\text {nd }}$ ed., New Delhi: Jaypee Brothers Medical Publisher (P) LTD, 2007, pp. 94-116, 163-174, 230-231, 246-247. 
[11] C.M. Marya, Epidemiology and etiology of malocclusion. A Textbook of Public Health Dentistry, 2011.

[12] T.D. Foster, Buku ajar ortodonsi, $3^{\text {th }}$ ed., Jakarta: ECG, 1993, pp. 30-38,174-179,192-209.

[13] S.I. Bhalajhi, Classification of malocclusion. Orthodontics the art and science, 2004, pp. 63-70.

[14] S.I. Bhalajhi, Ortodontics the art and science. $3^{\text {th }}$ ed., New Delhi: ARYA (MEDI) Publishing House, 2003, pp. 63-74,177178, 239-246, 259-260.

[15] C. Frindel, "Practical orthodontic rubric: Clear thinking about interproximal stripping," JDAO, vol. 13, pp. 187-188, 2010.

[16] K.J. Ram, "Evaluation of crowding in relation to tooth size, arch size, and arch form in North-east Indian population," J. Pharm. Biomed. Sci., vol. 31(31), pp. 1199-2000, 2013.

[17] M. Poosti, T. Jalali, "Tooth size and arch dimension in uncrowded versus crowded class I malocclusion," Journal of Contemporary Dental Practice, vol. 8(3), pp. 3, 2007.

[18] A.D. Mahmood, "A comparative study of tooth size and dental arch dimension between Iraqi Arabs and Kurds with class I normal occlusion," Al-Rafidan Dent. J., vol. 12(1), pp. 71-79, 2012.

[19] I.E. Rieuwpassa, S. Toppo, S.D. Haerawati, "Perbedaan ukuran dan bentuk lengkung gigi antara laki-laki dan perempuan suku Bugis, Makasar, dan Toraja," Dentofasial, vol. 11(3), pp. 156$160,2012$.

[20] F.A. Kareem, T.A. Rasheed, A.M. Rauf, "Longitudinal changes indental arch circumference in Sulaimani city," J. Eur. Scientific, vol. 9(18), pp. 109-119, 2013.

[21] D.R.A. Alpiah, P.S. Anindita, Juliatri, "Ukuran dan bentuk lengkung gigi rahang bawah pada suku Minahasa," J. eGigi, vol. 3(2), pp. 373-378, 2015.

[22] N.M. Al-Zubair, "Dental arch asymmetry," Eur. J. Dent., vol. 8(2), pp. 224-228, 2014.

[23] T. Rakosi, Cephalometric radiography, Wolf Medically, 1982, pp. 55-95.

[24] A. Jacobson, Radiographic cephalometry from basic to video imaging, Quintessence Publishing, 1995, pp. 95-97.

[25] G.I. Isiekwe, O.O. daCosta, M.C. Isiekwe, "A cephalometric investigation of horizontal lip position in adult Nigerians," vol. 39, pp. 160-169, 2012. 